\title{
Relationship Between Spiritual Well-Being Towards Children's Temperament and Pain Scale During Invasive Action
}

\author{
$1^{\text {st }}$ Y Sofiyah \\ Pediatric Nursing Department \\ Sekolah Tinggi Ilmu Kesehatan \\ 'Aisyiyah Bandung \\ Jl.K.H. Ahmad Dahlan Dalam No. 6, \\ Bandung, Indonesia \\ ovieys@gmail.com
}

\author{
$2^{\text {nd }} L$ Nurhidayah \\ Student, Undergraduate Study \\ Program, Sekolah Tinggi Ilmu \\ Kesehatan 'Aisyiyah Bandung \\ Jl.K.H. Ahmad Dahlan Dalam No. 6, \\ Bandung, Indonesia
}

\begin{abstract}
This study is motivated by children who experience health problems such as illness and require them to undergo treatment at the hospital, so it will affect the physical and psychological conditions such as feeling scared and anxious. Fear or anxiety occurred in children is caused by invasive measures such as infusion and blood collection. When children feel stress due to invasive actions, it will affect the pain they feel. In this case, temperament is one of the characteristics of children that can affect interactions between children and parents, especially mothers as primary caregivers, are things that are obtained by children because of parenting. Therefore, the factors that can influence it are spiritual and temperament because it can reduce pain. This study was aimed to acknowledge the relationship of spiritual well-being towards children's temperament and pain scale during invasive action. The design of this study used crosssectional on 72 children aged 8 to 18 years using consecutive sampling techniques. This data used bivariate analysis with Spearman rank. The results of this study indicated there was a relationship between spiritual well-being and children's temperament (p- value: 0.018 ) and the scale of pain on children during an invasive action ( $p$-value: 0,000). It is suggested to further enhance nursing care, especially on spiritual care for children that can affect the children's temperament and pain scale during invasive actions.
\end{abstract}

Keywords-Spiritual Well, Children, Temprament, Pain Scale, Action

\section{INTRODUCTION}

Every child has a comprehensive opportunity to grow and develop optimally both physically, mentally, and socially. To achieve optimal growth and development of children, it depends on several factors such as genetic, biological, psychological, social, and behavioral. If these factors are disrupted, there will be problems with the growth and development of children [5]. One of the disorders that occur in children is sick. Nisha and Umarinai [1] revealed that when a child experiences pain and requires him to undergo treatment at the hospital, it will affect his physical and psychological condition. According to Wong [2], generally, children who are treated at the hospital will feel fear, and think that they will be hurt. At This time, the children will experience that makes him traumatized or stressed. This is called a hospitalization.

Supartini [3] explained that hospitalization is a condition that makes children, parents, and families worry. The effects shown in children depend on their development and growth, pain, anxiety, and loss. Hockenbery and Wilson [4], showed that hospitalization is a reaction or stressor for someone who is doing treatment in a hospital. Kyle and Carmas [5], revealed that anxiety that occurs in children occurs due to a planned action or in an emergency. The causes of stress in children also vary - for example, anxiety due to separation of bodily injury and pain [4]. This will cause the children to feel uncomfortable when an action that causes pain. Pain experienced by children arises due to several factors. Factors that can be related to pain reactions include internal factors such as age, temperament, fear, gender, and previous experience of pain, and external factors [6]; [7]). Rahayu [8] said that children's temperament. influences pain.

Associated with the occurrence of hospitalization in children, it is indicated that the role performed by the family adaptively is much influences on the goals and achievements of children who undergo treatment in the Hospital [3]. One of the factors that influence anxiety is spirituality [9]. Spiritual has an influences on anxiety, which can reduce anxiety in children and mothers. The spiritual state of the children is directly related to the spiritual condition of the parents. Spiritual is an essential aspect of helping a person achieve the harmony needed to maintain health and well-being, and to be oriented towards his illness [10]. Anxiety occurs not only in children, but also occurs in parents such as distrust of sudden and severe illness. Other feeling, such as anxiety, fear, and frustration, 
are related to the condition of the disease and invasive actions taken. However, the enormous strength experienced is in the form of trauma and pain felt by children [2]. When children experience pain, parents will experience emotional problems such as anxiety, sadness, and symptoms of post-traumatic stress, but that is a fundamental problem for parents when their children are sick [11].

Based on the description above, the children's anxiety cannot be separated from the anxiety of parents. Since the parents are the closest people to children, all children's behavior is a reflection of parents' behavior. In this case, temperament is one of the characteristics of children that can influence interactions between children and parents, especially mothers as primary caregivers [12]. Also, it is something that is obtained by children because of parenting. Based on Rahayu's [8] research on the analysis of factors related to pain reactions due to invasive actions on children hospitalized in RSUD Bekasi, it was found that children's temperament influences the response of pain in children during invasive activities.

Research conducted by Cotton, Grossoehme, Rosenthal, and Tsevat [13], about spiritualist 0in children and adolescents who experience sickled cell disease. it was obtained that most of the children suffering the condition have high spiritual well-being and positive religious coping, and so do the parents. According to Sofiyah, Hayati, and Nurhaeni's research [14], the factors influencing children's spiritual well-being include the parents' spiritual well-being, the parents' tribe, cancer diagnoses, parental education, and recurrence status.

\section{METHOD}

The method used in this study was cross-sectional that focuses on the measurement or observation of independent and dependent variables carried out only at that time or once [15]. The total respondents used in the data collection were 72 by using consecutive sampling techniques. Measuring instruments used in this study were in the form of a questionnaire consisting of Respondent Characteristic Data Questionnaire including age, gender, education level, worship, habits, and invasive actions are taken. Children's' spiritual well-being instrument included 10 statement items, then, they were divided into two subsections namely religious wellbeing and existential well-being with a score ranging from 0 to 27, the Children's Temperament Scale using the Behavioral Style Questionnaire for children aged three -7 years from Carey and Mc Devitt (1978) in Wong [2] that has been used by Pelitawati [16] and Rahayu [8] with a Likert scale divided into three categories.

This study used univariate analysis describing the demographic variables are, age, education, gender, race, habits of worship, and prayer. The invasive actions were presented in the form of frequency distribution and percentage. The test used in this study in the bivariate analysis used the Spearman Rank.

\section{RESULTS}

Respondents in this study numbered 72 , consisting of a couple of parents and children, The description of the characteristics of parental respondents was in table I.

TABLE I. DISTRIBUTION OF RESPONDENTS PAIN SCALE $(\mathrm{N}=72)$

TABLE I. DISTRIBUTION OF RESPONDENTS PAIN SCALE (N = 72)
\begin{tabular}{|l|c|c|}
\hline \multicolumn{1}{|c|}{ Characteristics } & Frequency & Percentage $(\%)$ \\
\hline Pain Scale & & \\
\hline $0=$ No pain & 15 & 20.8 \\
\hline $1-3$ = Mild Pain & 29 & 40.3 \\
\hline $4-6$ = Moderate pain & 19 & 26.4 \\
\hline $7-10$ = Severe pain & 9 & 12.5 \\
\hline
\end{tabular}

According to Table I, the distribution of respondents based on the pain scale indicated that there were 29 respondents were having a scale of 1-3 - that is, mild pain $(40.3 \%)$.

\begin{tabular}{l} 
TABLE II. DISTRIBUTION OF RESPONDENTS BASED ON SPIRITUAL WELL-BEING $(\mathrm{N}=72)$ \\
\hline
\end{tabular}

Table II Distribution of children's spiritual well-being showed that of the 72 respondents, 55 respondents $(76.4 \%)$ had high spiritual well-being, and four respondents $(5.6 \%)$ had low spiritual well-being.

TABLE III. DISTRIBUTION OF RESPONDENTS BASED ON THE CHILD'S TEMPERAMENT $(\mathrm{N}=72)$

\begin{tabular}{|c|c|c|c|}
\hline No & Children's temperament & $\mathrm{n}$ & $\%$ \\
\hline 1 & Slow to be temperament & 63 & 87.5 \\
\hline 2 & Easy to be temperament & 9 & 12.5 \\
\hline \multicolumn{2}{|r|}{ amount } & 72 & 100 \\
\hline
\end{tabular}


Table III Distribution of children's temperament showed that the majority of respondents were in slow to be temperament as many as 63 respondents $(87.5 \%)$.

TABLE IV. RELATIONSHIP OF SPIRITUAL WELL-BEING AND CHILDREN'S TEMPERAMENT (N = 72)

\begin{tabular}{|c|c|c|c|c|c|c|c|}
\hline \multirow{3}{*}{ Spiritual Well-Being } & \multicolumn{4}{|c|}{ Children's temperament } & & & \\
\hline & \multicolumn{2}{|c|}{ Slow } & \multicolumn{2}{|c|}{ Easy } & \multicolumn{2}{|c|}{ Total } & $\mathrm{P}$-value \\
\hline & $\mathrm{n}$ & $\%$ & $\mathrm{n}$ & $\%$ & $\mathrm{n}$ & $\%$ & \multirow{4}{*}{0.018} \\
\hline Low & 3 & 4.2 & 1 & 1,4 & 4 & 5.6 & \\
\hline Medium & 9 & 12.5 & 4 & 5.6 & 13 & 18.1 & \\
\hline High & 51 & 70.8 & 4 & 5.6 & 55 & 76.4 & \\
\hline Total & 63 & 87.5 & 9 & 12.5 & 72 & 100.0 & \\
\hline
\end{tabular}

Based on the results of table IV, it was indicated that $\mathrm{p}$ value $<0.05(\mathrm{p}=0.018)$. It was showing that $\mathrm{H} 0$ was rejected and Ha was accepted, so it can be concluded that there was a significant relationship between spiritual wellbeing and children's temperament with coefficient correlation $=-0.278$. It can be seen that the strength of the relationship among the two variables, where the range of strength values was weak so that the relationship between spiritual well-being and children's temperature in Rumah Sakit Umum Daerah Al-Ihsan West Java Province had weak strength with negative correlation direction or unidirectional correlation. It indicated that if they had high spiritual well-being, the children's temperament was at a slow temperament.

TABLE V. RELATIONSHIP BETWEEN SPIRITUAL WELL-BEING AND PAIN SCALE DURING INVASIVE (N = 72)

\begin{tabular}{|c|c|c|c|c|c|c|c|c|c|c|c|}
\hline \multirow{3}{*}{$\begin{array}{l}\text { Children's } \\
\text { spiritual well- } \\
\text { being } \\
\end{array}$} & \multicolumn{8}{|c|}{ Pain Scale } & & & \\
\hline & \multicolumn{2}{|c|}{ No pain } & \multicolumn{2}{|c|}{ Mild Pain } & \multicolumn{2}{|c|}{ Moderate Pain } & \multicolumn{2}{|c|}{ Severe pain } & \multicolumn{2}{|c|}{ Total } & P-value \\
\hline & $\mathbf{n}$ & $\%$ & n & $\%$ & n & $\%$ & n & $\%$ & $\mathbf{n}$ & $\%$ & \\
\hline Low & 0 & 0 & 0 & 0 & 0 & 0 & 4 & 5.6 & 4 & 5.6 & \multirow{3}{*}{0,000} \\
\hline Medium & 0 & 0 & 1 & 1,4 & 6 & 8.3 & 6 & 8.3 & 13 & 18.1 & \\
\hline High & 17 & 23.6 & 24 & 33.3 & 9 & 12.5 & 5 & 6.9 & 55 & 76.3 & \\
\hline Total & 17 & 23.6 & 25 & 34.7 & 15 & 20.8 & 15 & 20.8 & 72 & 100 & \\
\hline
\end{tabular}

Based on the results of table $\mathrm{V}$, it was known that there was a $\mathrm{p}$-value $<0.05(\mathrm{p}=0,000)$. This indicated that $\mathrm{H} 0$ was rejected and $\mathrm{Ha}$ was accepted so that it can be concluded that there was a significant relationship between spiritual well-being and pain scale on children during invasive action with coefficient correlation $=-0.595$. It can be seen that there was the strength of the relationship among the two variables, where the range of strength values was 0.51 - 0.75 so that the relationship between spiritual well-being and the pain scale on children during invasive action in Rumah Sakit Umum Daerah Al-Ihsan West Java Province had a durable power with the negative correlation direction or unidirectional correlation. It indicated that the more the spiritual well-being, the lower the pain scale.

\section{DISCUSSION}

Based on the results of the study, it was found that $76 \%$ of children hospitalized in Rumah Sakit Umum Daerah AlIhsan West Java Province were at a high level of spiritual well-being. If being seen from the way of worshiping respondents, there were $66.7 \%$ who always did worship and $68.1 \%$ who did prayer every time. Cotton, Grossoehme, Rosenthal, and Tsevat [13] described the spirituality of children and adolescents experiencing sickled cell disease indicated the results of high spiritual wellbeing and positive religious coping. According to Potter \& Perry [10], patients who have intense spirituality will form a good personality: also addition they will consider the pain felt like an obstacle or trial, and always think positively.

Based on a literature review, the person who has high spiritual well-being has a good character, a life view based on religious values, and a purpose in life, He or she creates prayer as an essential part of life, believes in life after death [17], has a spiritual belief (adheres to a religion) and believes in the highest strength, namely God. Meanwhile, according to the Qur'an and Hadith, the characteristics of a spiritually prosperous person are to have a calm heart (Surah Ar-Ra'du verse 28), kind words, smooth face (Surah Az-Zumar verse 23), the excellent hearing, vision and a high level of sensitivity of the heart (Surat An-Nahl verse 78), a glowing face (Surah Al-Fath verse 29), humble, right speech, diligent to do tahajud prayers, simple life (Surah Al-Furqon verse 68) and a healthy and fit physique (Al-Hades) .

In this study, it was not examined about the spiritual well-being of respondents' parents. However, from the results of this study, it was indicated that the high level of the respondents was depended on the parents' spiritual well-being. From the research conducted by Schneider and Mannell [18], the theory of spiritual influence gives an understanding of how children and families use the process of maintaining the spirit of life in response to the phenomenon of cancer treatment. From the study's result of Sofiyah, Hayati, and Nurhaeni [14], it was 
concluded that there is a relationship between the spiritual well-being of parents and the children and cancer, as stated in the Qur'an, the At-Tahrim verse 6.

From this study, it was found that there was a relationship between spiritual well-being and children's temperament ( $\mathrm{p}$-value 0.018). Parenting behavior has a significant influence on children's mental health, and it can contribute to emotional development or behavior problems in children. Differences in parenting behavior are associated with parental personality and children's temperament [19]. This is reinforced by Desmita [20], explaining that at this stage following the stages of development and cognitive in children that the beliefs owned by children are imitating because the trust they have is still the result of the education or guidance of adults or their parents. According to Hamid [9] that the role of parents is very determining on children's spirituality because the children will learn about God, the meaning of life, and the behavior of their parents. Temperament can affect the achievement of children's lives and will continue to carry over into adulthood and for life. Although temperament comes from biological factors, it is nota destiny that cannot be changed [21].

Based on the results of this study, it was found that there was a significant relationship between spiritual well-being and pain with coefficient correlation $=-0.595$ with negative correlation or unidirectional correlation and $\mathrm{p}$ value $=0,000$ with the meaning that when the respondent had high spiritual well-being, the pain scale would be low and vice versa. The things that can create children's spiritual well-being and pain scale have a relationship due to several factors following the characteristics of respondents such as age, worship, prayer, and religious coping that they have got from their parents and environment. This is reinforced by the study of Cotton, Grossoehme, Rosenthal, and Tsevat [13], about the spirituality of children and adolescents who experience sickled cell disease showing high spiritual wellbeing and positive religious coping. According to Potter \& Perry [10], it was acknowledged that the patients who are spiritually healthy patients would form a good personality, besides they will consider the pain felt like an obstacle or trial, and always think positively.

\section{CONCLUSIONS}

The results of the respondents' spiritual well-being had a high level of spiritual well-being $(76.4 \%)$. There was a relationship between spiritual well-being and children's temperament $(\mathrm{r}=-0.278 \mathrm{p}$-value 0,0018$)$ and also pain scale in children during invasive action in Rumah Sakit Umum Daerah Al-Ihsan West Java Province $(r=-0.595$; $\mathrm{p}$ value $=0,000)$.

\section{REFERENCES}

[1] Nisha. K and Umarinai. "Effect of play Intervention in The Reduction Of Anxiety Among Preoperative Childer," J. Dep. Pediatr. Nursing, Yenepoyu, Nurs. Collage, Yenepoyu Univ. Deralakatte, Mangalor, Karnataka, India Int $j$ Cur Resrev, vol. 05, 2013.

[2] Wong, Buku Ajar Keperawatan Pediatrik. Jakarta: EGC, 2009.

[3] Supartini, Buku Ajar Konsep Dasar Keperawatan Anak. Jakarta: EGC, 2004

[4] Hockenberry and Wilson, "Wong's Essential of Pediatric
Nursing," vol. Vol 9, 2013.

[5] Kyle and Carmas, Buku Ajar Keperawatan Pediatri. Jakarta: Wolters Klower EGC, 2015.

[6] LeMone and Burke, Medical surgical nursing : Critical thinking in client care. New Jersey: Pearson Prentice Hall, 2008.

[7] Czarnecki, Turner, Collins, Doellman, Wrona, and Reynolds, "Procedural Pain Management: A Position Statement with Clinical Practice Recommendations," Pain Manag. Nursing, 12(2), 95-111, 2011, doi: 10.1016/j.pmn.2011.02.003.

[8] Rahayu, "Analisis Faktor-faktor yang Berhubungan dengan Reaksi Nyeri Akibat tindakan Invasif Pada anak yang dieraway di RSUD Kota Bekasi. Tesis. Fakultas Ilmu Keperawatan Universitas Indonesia Depok,” 2015.

[9] Hamid, Metode Penelitian Kualitatif Aplikasi Praktis Pembuatan Proposal Penelitian dan Laporan. Malang: UMM Press, 2007.

[10] Perry and Potter, Fundamental of Nursing. Jakarta: Salemba Medika, 2010.

[11] Churchill, Villareale, Monaghan, Sharp, and Kiechefer, "Parents of Childern With Special Helath Care Needs Who Have Better Coping Skills Have Fewer Depressive Symptoms," Matern Child Heal. J, 2010, doi: 10.1007/s10995-008-0435-0.

[12] Ball and Bindler, Pediatric nursing: Caring for children., 3rd ed. New Jersey: Prentice Hall, 2003.

[13] Cotton, Grossoehme, Rosenthal, and Tsevat, "Religious/spiritual coping in adolescents with sickle cell disease: a pilot study," J Pediatr Hematol Oncol, vol. 31(5): 313, 2010, doi: 10.1097/MPH.0b013e31819e40e3.

[14] Sofiyah, Haayati, and Nurhaeni, "Kesejahteraan Spiritual Anak Beperngaruh Terhadap Kulitas Hidup Annak Yang Mengalami kanker," J. Kesehat. “Caring Enthusiasm," vol. 17, 2017.

[15] Nursalam, Metodelogi Penelitian ilmu Keperawatan: Pendekatan Praktis (4 ed.). Jakarta: Salemba Medika, 2017.

[16] Pelitawati, "Pengaruh permainan terapeutik terhadap kecemasan, kehilangan kontrol, ketakutan anak prasekolah selama dirawat di RSUD Dr. H. Abdoel Moeloek Provinsi Lampung. Tesis. Fakultas Ilmu Keperawatan Universitas Indonesia Depok," 2009.

[17] Young and Koopsen, "Spirituality, Health, And Healing. An Integrative Approach". Second Edition,” 2011.

[18] M. A. S. \&Roger C. Mannell, "Beacon in the Storm: An Exploration of the Spirituality and Faith of Parents Whose Children Have Cancer," no. Issues in Comprehensive Pediatric Nursing 29(1):3-24, 2006, doi: 10.1080/01460860500523731.

[19] Achtergarde, Postert, Wessing, Romer, and Muller, "Parenting and child mental health: influences of parent personality, child temperament, and their interaction The Family Journal: Counseling and Therapy for Couples and Families.," 2014, doi: 10.1177/1066480714564316

[20] Desmita, Psikologi Perkembangan Peserta Didik. Bandung: PT Remaja Rosdakarya, 2009.

[21] Rebecca L. Shiner, "The Impact of temperament on child development: Comments on Rothbart, Kagan, Eisenberg, and Schermerhorn and Bates," Encyclopedia on Early Childhood Development. pp. 1-5, 2012. 